\title{
Monitorering av hjerte-muskelfunksjon med epikardielle ultralydtransducere
}

Andreas Westenvik Espinoza ved Institutt for klinisk medisin, Universitet i Oslo forsvarte den 24. oktober 2013 sin avhandling for graden ph.d:

Monitoring of myocardial function by epicardial ultrasonic transducers

Ved komplisert hjertekirurgi er myokardiskemi en viktig risikofaktor, som er viktig å oppdage tidlig. Ultralyd gjør dette bedre enn EKG og blodtrykksmåling, men metoden er diskontinuerlig og krever en erfaren undersøker. Espinoza og medar- beidere utviklet derfor en metode for kontinuerlig ultralydovervåking. I dyremodellen kunne metoden oppdage myokardiskemi tidlig samt at det var mulig å skille dette fra forandringer fremkalt av medikamentell eller væskebehandling. Hos pasienter under hjertekirurgi påviste metoden myokardiskemi tidlig ved blant annet hjelp av automatisert signalanalyse. Metoden muliggjør kontinuerlig overvåking av hjertefunksjon hos pasienter $\mathrm{i}$ forbindelse med hjertekirurgi, og kan forenkle og forbedre bedside diagnostikken. 